\title{
Edward Wright
}

ORCID: https://orcid.org/0000-0002-1822-2408

Bournemouth University, United Kingdom

The University of Malta, Malta

\section{Voicing the Longing \\ of the "Adolescent Heart" \\ through Photography and Film: \\ Connecting Transcendence \\ and Revelation in Catholic Religious Education}

\begin{abstract}
This paper explores how through narrative pedagogies inspired simultaneously by divine pedagogy revealed in Scripture and the power of modern media to visually represent the human heart's most profound longings, divine revelation can, through Catholic Religious Education (CRE), reach and transform adolescent hearts. Such a transformation is made possible through adolescents' expression of transcendence in a communal context that is facilitated when metaphor's power in helping adolescents tell stories about themselves is unlocked through photography and film. These media teach young people use their capacity for imagination and critical thinking more effectively and produce narratives of self through which they narrate who they are and would like to be. Such media impact identity through the process of merging words, imagery, music and movement, and can be so dynamic and effective in representing self. CRE can thus enable young people to become critical, even of their own past experiences, make them more integrated and coherent, empower them to meet life's challenges, and afford them the opportunity to project their lives in the future as they wish them to be. All throughout such a process, adolescents learn more what God's revelation entails and its potential to make human life more beautiful and meaningful.
\end{abstract}




\section{Keywords}

Revelation, transcendence, catholic religious education (CRE), adolescence, narrative pedagogy, photography and film.

\section{Abbreviations \\ Catholic Religious Education (CRE) \\ Media Literacy Education (MLE) \\ Digital Art (DA)}

\section{Introduction}

In every CRE syllabus that is designed to be part of a school curriculum across the primary and secondary school years of any educational system, one would expect to find the topic, or rather the notion of revelation, to be both present and prominent. Such expectation is simultaneously understandable and justifiable, since Catholicism, and thus Catholic theology, are mainly founded on the revelation of God in human history, especially in the historical existence of and salvation brought to mankind by Jesus Christ.

However, a question which has always dominated my critical reflection as a CRE teacher for more than twenty-three years is that which grapples with the relationship that exists between God's revelation and human experience, and thus between a CRE syllabus and the concrete everyday life experiences of adolescents. One personal experience from the CRE classroom that I always vividly recollect from my distant memory of my professional life as a CRE teacher is when I was explaining to my students and commenting on a quotation from the Book of Revelation: "And I heard a loud voice from the throne saying, "Look! God's dwelling place is now among the people, and He will dwell with them. They will be his people, and God himself will be with them and be their God. 'He will wipe every tear from their eyes. There will be no more death' or mourning or crying or pain, for the old order of things has passed away."' The main learning outcome of that lesson was that the students reflect upon how God's love for every human being is mostly revealed through his compassionate presence in human experiences, especially those that bring about so much

\footnotetext{
${ }^{1}$ Revelation 21:4.
} 
pain, anxiety, fear, distress, anger and frustration. Moreover, I still remember how, to demonstrate such a foundational Christian truth, I had visually projected to the students images of Jesus performing miracles of healing and even of resurrecting people from death. As I was speaking with the conviction and passion that transpired from my Catholic faith, one 13 year-old student raised his hand to speak. Briefly, but emotionally, he shared several experiences of grief and loss that he had experienced already in his life, and then asked me, "how has God wiped my tears, and how has He been present in my life? As I have been crying and mourning for a long time now, and it seems that nothing can console my heart!" From that moment onward I firmly believed that the relevance of CRE in the school curriculum can only transpire from the extent to which its content and pedagogy can make God's promises really felt in the concrete human experiences of adolescents and young people.

\section{Questions and Challenges that Define the Quest for Relevance of CRE}

Thus, the three main interrelated questions that are addressed in this paper, and that have shaped my critical reflection all along my professional journey as a CRE teacher, lecturer and mentor as well as my endeavour to explore imaginatively how the relevance of CRE ensues from the relationship between God's revelation and human experience, are the following:

- How does God reveal Himself in human experience?

- How can this revelation of God be transmitted in CRE through a narrative-hermeneutical-developmental approach to learning?

- In our digital age, how can the relevance of CRE, transpiring from such a relationship, be felt in adolescence through the application of creative media and digital technologies?

It is my firm conviction as a CRE educator, formed through my reflection on both my own personal and professional experience, and the academic formation and transformation I have experienced, that such questions and challenges could only be adequately addressed if God's revelation to and communication with the human person are located in the transcendental space within the parameters of human experience. Most of the adolescent students I had the privilege of teaching as a CRE teacher would acknowledge that CRE could, as a curricular subject, be very relevant to their lives as long as its potential to engage with 
human experience is unlocked. They believe that such engagement, combined with the educator's sense of empathy and compassion for students' experiences of pain, fears and anxieties, can bring about the strengthening of relationships of respect and true love in a community of learning as well as a sense of healing, invaluable sources of resilience in the face of life's adversities.

\section{Locating God's Revelation in Human Transcendence: a Rahnerian Perspective}

One of the strongest objections that I face from some CRE teachers and lecturers when I speak my mind about the need to locate God's revelation in the transcendental space of the human heart and mind, is that such belief would only serve to dilute the content of CRE. It would make it another humanity subject that just seeks to provide opportunities for students to voice themselves and learn from each other possible solutions for their everyday problems and challenges. To such an objection, many times stemming out of genuine fear that CRE would be stripped off its unique status and distinct characteristics, especially those of transmitting God's revelation in the history of mankind and teaching the doctrinal tenets of the Christian creed as the main vehicle of that revelation, I give an answer that draws upon the stance on the notion of human transcendence taken by the German Jesuit theologian Karl Rahner.

Through this stance Rahner became, with Bernard Lonergan, one of the best known exponents of the Transcendental Thomist school of Catholic theology. This approach built on the attempts by the Belgian Jesuit Joseph Marechal to re-read St. Thomas in the light of Kant's critical philosophy. Rahner's point of departure of metaphysics became the human subject rather than Being. Influenced by Hegel (especially his dialectic of dialectic of spirit and world) and by Heidegger's phenomenological ontology in relation to the question of Being, for Rahner metaphysics came after cognitional theory and epistemology. He strongly believed that this "turn to the subject" is unavoidable for Christianity to engage in real dialogue with modernity. The German Jesuit was also deeply affected by the Ignatian Spiritual Exercises and the Ignatian "from below" that takes systematic shape in his Transcendental Thomism with its stress in philosophy and theology on the pivotal role of human inner experience.

For Rahner, human language is always deficient and incapable of fully expressing the unthematic experience of a movement from God, or the original 
experience of self-possession. ${ }^{2}$ Since religious language and theological conceptualizations are inadequate to express the object of their reflection, they must always, necessarily, be referred back to the experience which they seek to articulate. "Reflection, conceptualization and language have a necessary orientation to that original knowledge, to that original experience in which what is meant and the experience of what is meant are still one."3

Rahner distinguishes between an original experience - the experience of an encounter with God as the one who calls us to a deeper understanding of ourselves - and the reflection on that experience. For him one's experience of God strives to express itself in concepts. This belief combines together the rationalist's belief that only the reflection/concept of the experience is real, and the modernist's belief that reflection is second-hand experience, an attempt to understand something which, in its original state, is much more fundamental. So while acknowledging that the experience of God strives to express itself in concepts, Rahner also expresses his strong belief that the thematization is incapable of adequately articulating in words the subject's original experience of itself. Rahner himself states that "it never recaptures this original, subjective self-presence completely." ${ }^{4}$ Such inadequacy that transpires from the very nature of God and how human beings experience Him, is at the heart of Rahner's theology, mainly characterized by his understanding of and insight into transcendence. In fact, through the transcendental nature of his theology, Rahner expresses his deep insight about man's ability to overcome his own limitations by reflecting on them. This truth plays a particularly significant role in human reflection on life's meaning, since as someone reflects on the limitations of that meaning, paradoxically feels a desire and deep sense of longing for greater meaning. According to Rahner, deeply embedded in this experience, and profoundly present in this intuition, is an indirect knowledge of God who facilitates meaning and invites us to articulate it conceptually. This means that whenever humans acquire any form of knowledge, then simultaneously gain more knowledge about and insight into ourselves. Moreover, despite all forms of conditioning that knowledge is subjected to, humans remain open to experience. This is an experience of transcendence that is mainly characterized by its ability to provide us with indirect knowledge of God as the Creator who presents us with challenges and

\footnotetext{
${ }^{2}$ P. Knitter, Theologies of Religions, New York 2002, p. 68.

K. Rahner, An Introduction to the Idea of Christianity, New York 1978, p. 17.

${ }^{4}$ K. Rahner, An Introduction to the Idea of Christianity, New York 1978, p. 19.
} 
choices, out of his great love for humans. This experience becomes a condition of possibility to experience all concrete objects. ${ }^{5}$ Thus, in the silent depths of transcendental experience, God can become known, anonymously and unthematically.

In this Rahnerian perspective, language is understood to be a crucially important and necessary tool to articulate the human knowledge of God. However, it simultaneously falls short of adequately capturing, describing and expressing one's personal encounter with God. In Rahnerian terms, language is, always and inevitably, a trace of transcendence. While Rahner acknowledges and reflects at length about its importance, he warns against the ever present temptation to incarcerate the transcendence and openness of spirit in the material. God, according to the German theologian, can and should never be narrowly defined and neatly contained in human concepts. If language becomes its own ultimate referent, it ends up being a finite, closed system, something that we always need to avoid at all costs. ${ }^{6}$

\section{Revelation as Symbolic Mediation}

Intimately related to Rahner's perspective on the role of language is his reflection about the nature and role of the symbolic. In this respect, his main focus is on the expressive nature of symbol as "the representation which allows the other to be there." As human beings, our need for expression is deeply imbued in our nature, and in expressing ourselves we become present to ourselves. In this sense, the appearance becomes central to the nature of symbol, and as Rahner puts it, it may seem that he is reducing the importance of the form of the symbol: "it does so by really projecting its visible figure outside itself as its symbol, its appearance, which allows it to be there, which brings it out to existence in the world: and in doing so, it retains it - 'possessing itself in the

${ }^{5}$ K. Rahner, An Introduction to the Idea of Christianity, New York 1978, p. 20; G. Rossiter, Understanding the Changing Landscape of Contemporary Spirituality: A useful starting point for reviewing Catholic school religious education, "The Person and the Challenges" 3 (2013) No. 1, pp. 157-179.

${ }^{6}$ K. Rahner, An Introduction to the Idea of Christianity, New York 1978, p. 30.

${ }^{7}$ K. Rahner, The Theology of the Symbol, “Theological Investigations”, vol. 4, p. 225. Henceforth, the series will be denoted by TI and volume number. 
other"'" This may also give some the impression that Rahner is diminishing the importance of the role of language due to its inadequacy to capture and articulate one's original and transcendental experience of God. However, while acknowledging the limitations of human language, the German theologian simultaneously emphasizes its importance and vitality. He explicitly states that "the symbol belongs intrinsically to what is expressed..." and that "everything is redeemed by the word which is the perfection of all things." ${ }^{\text {"10 }}$ This importance to language is demonstrated even more by Rahner through the way he connects it to his notion of "primordial words." These are for him sacramental in that they simultaneously embody and make present their referent, and they incarnate and manifest the transcendence they articulate in the very otherness of the expression. Such words are for Rahner "sacral and even sacramental, in the sense of helping to effect what they signify and penetrate creatively into the primordial centre of man."11 In his mind, there are no specific words that could be listed, defined or described as primordial. What can make words as such is their power to open man to transcendence, and to express it, albeit in a limited manner. He refers to primordial words in lyrical, even poetic ways. His efforts are more directed at characterizing, rather than just justifying his way of conceiving these words. It is however clear that "his characterization is grounded in his notion of the human person as spirit in the world."' ${ }^{\prime 2}$ This transpires from his conviction that human existence is a dynamic openness for God in this world of human beings. Moreover, it is particularly in the word, that this is concretized. The word, for Rahner, is not merely a vehicle for human thought, but the corporeal state in which this thought is achieved. Thus, the word is itself an integral part of the movement of our knowing, freedom, and love toward fulfilment. Consequently, words are not mere expressions of human transcendence but a concrete manifestation, acquisition and expression of this transcendence. Rahner's conception of primordial words and their role in human transcendence transpires from the close connection he posits between

K. Rahner, The Theology of the Symbol, “Theological Investigations” vol. 4, p. 231.

K. Rahner, The Theology of the Symbol, “Theological Investigations”, vol. 4, p. 234.

${ }^{10}$ K. Rahner, Priest and Poet, in: TI 3, 300.

${ }^{11}$ K. Rahner, Poetry and the Christian, in: TI 4, 360. Rahner wrote these words in 1960 where he explicitly mentions for the first time the concept of anonymous Christianity. This was about a year and a half before the onset of Vatican Council II. See especially, p. 366.

${ }^{12}$ R. Masson, Rahner's Primordial Words and Bernstein's Metaphorical Leaps: The Affinity of Art with Religion and Theology, "Horizons", Vol. 33, 2 (2006), pp. 276-297. 
anthropology and grace, as primordial words emerge from the depths of the human heart. Since for Rahner, humanity must be structured as openness and desire to receive God's offer of love, human nature is not just 'natural' but graced, as the human being could feel the power, presence, warmth and peace of God. This insight into this divine reality of the human inner profound self through transcendence, made Rahner coin the term 'supernatural existential. ${ }^{13}$ This Rahnerian belief implies that by being human, a human being is more than human, and so, to come in touch with one's humanity would translate into being touched by the divine, by the Spirit of God that transmits His love. Rahner describes his own concept of grace by applying the metaphor of electricity that lights up a light bulb to make it what it really is. This implies that the love of God does not just embrace humans but fills from within and enables to live and act differently. The more knowledge we acquire the more we feel the need to ask and inquire further, and the more we love and feel loved the more we long to embrace and be embraced by others. And yet, we are never satisfied. In the love we receive and feel from, or express and give to others, we always experience the pull of a greater love. We hear the voice within us of the Infinite who is beyond us. It is in this way that human nature is truly graced, and through such a perspective and understanding of our nature, Rahner could argue that "the primordial words of human beings transmuted by the Spirit of God are allowed to become words of God." ${ }^{\prime 4}$ Thus, human words can be potentially transformed into sacraments of divine love, in the sense of embodying a deeper spiritual reality from which they emerge. They can also function as symbols that allow a deeper mystery and accept the offer of grace, and in so doing they become more concretely present in and accessible to human lives.

Another very important work on the symbolic structure of revelation comes from Avery Dulles, undoubtedly one of the most noted American Jesuit theologians of the last century. In his book Models of Revelation, Dulles, whose teaching centred on "the possibility of revelation and its factual occurrence"15, asserts that God's revelation of himself and his love to human beings always comes across through symbolic mediation. He argues that this understanding of revelation encompasses all the other existing models (or understandings)

${ }^{13}$ K. Rahner, Foundations of Christian Faith, London 1978: Darton Longman \& Todd, p. 132.

K. Rahner, Priest and Poet, in: TI 3, 296.

15 A. Dulles, Models of Revelation, Doubleday \& Company (1983), p. vii. 
of revelation: namely of revelation as doctrine, revelation as history, revelation as inner experience, revelation as dialectical presence, and revelation as new awareness. The advantage of such a model is that it embraces the areas of common agreement between all these other models, as well as Christianity's foundational beliefs on revelation they all revere, but at the same time it goes beyond their distinct divergences from which contradictions transpire.

Through the lens of "symbolic mediation" Dulles shows how God has always revealed himself through the use of symbols. Thus, symbols permeate in every mode of God's revelation, and are always God's main vehicle of his self-communication in human history. Samuel Taylor Coleridge, like many other poets, had affirmed that "it is by Symbols alone that we can acquire intellectual knowledge of the Divine."16 A century later the Irish poet William Butler Yeats, one of the foremost figures of zoth-century literature, expressed the profound significance of a symbol metaphorically by describing it as "indeed the only possible expression of some invisible essence, a transparent lamp about a spiritual flame; while allegory is one of many possible representations of an embodied thing, or familiar principle, and belongs to fancy and not to imagination: the one is a revelation, the other an amusement." ${ }^{17}$

In his essay 'The Symbolic Structure of Revelation', Dulles broadens significantly the spectrum of possibilities that God uses to reveal himself symbolically. In fact he refers to the symbols pertinent to divine revelation as "almost infinitely various. ${ }^{{ }^{18}} \mathrm{He}$ goes on to say that these may be: "Cosmic objects or natural occurrences, such as the sun, the moon, the wind, and the waves. Or they may be particular personages or historical events, such as Moses leading the Israelites out of Egypt or Jesus Christ crucified and risen. Or again, the symbols may be artefacts such as a temple or an icon. Further, they may be words or writings, such as the figurative language of the prophets and apostles or the sacred writings of a religious tradition. A true story, a myth, a parable - any of these can become a vehicle for the divine self-communication. Strictly speaking, there

${ }^{16}$ S. Happel, Response to William Van Roo, "Proceedings of the Catholic Theological Society of America" 32 (1977), p. 119.

${ }^{17}$ W.B. Yeats, William Blake and His Illustrations to the Divine Comedy, "Collected Works 6", Stratford-on-Avon: Shakespeare Head Press (1908), p. 138.

18 A. Dulles, The Symbolic Structure of Revelation, "The Catholic University of America”, 41:1 (1980), p. 56. This article reproduced in slightly revised form a colloquium presented to the Fellows of the Woodrow Wilson International Center for Scholars (Dec. 21, 1977). 
is nothing which could not, under favourable circumstances, become a symbol of the divine." ${ }^{19}$

Dulles then goes on to show that in speaking of revelation as symbolic disclosure, many theologians would agree on a broadly inclusive usage of the term 'symbol', including not only tangible and visible objects but also the "charged" language of speech that is "more-than-literal."

In the following section it will be argued how such language, and speech, are also very efficient vehicles for the expression and transmission of human stories that are shared in a community setting, and which have immense potential to also become constituted of 'primordial words' flowing out of human hearts to transform others. In so doing, they become priceless sources of freedom, compassion and love, that are poured from the heart of God to every person, through fellow human beings in community, and in becoming so, human stories gain special status as an integral part of God's revelation.

\section{Revelation through the Power of Shared Human Stories and Experiences}

Stories bring meaning into human lives, convey values and emotions, aid in reaffirming and validating our lives and experiences, and have the ability to connect us with our inner selves, with others and with society. ${ }^{21}$ Human beings have the unique ability, simultaneously a basic need, to construct life narratives out of events that are turns into stories which contain beginnings, middles, and ends. ${ }^{22}$ Moreover, in humans there is a deep, intimate and significant connection between such a narrative process, through which we give meaning to our lives, and spirituality. ${ }^{23}$ As Atkinson (1995) states, "everything we encounter that gives

19 A. Dulles, The Symbolic Structure of Revelation, "The Catholic University of America" 41:1 (1980), p. 56.

${ }^{20}$ A. Dulles, The Symbolic Structure of Revelation, "The Catholic University of America" 41:1 (1980), p. 57.

${ }^{21}$ R. Atkinson, The life story interview, in: G.J.F. Holstein (Eds.), Handbook of Interview Research: Context and Method, Sage Publications 2002, Thousand Oaks CA, pp. 121-140.

${ }^{22}$ D.E. Polkinghorne, Narrative Knowing and the Human Sciences, State University of New York Press 1988, New York NY.

${ }^{23}$ W.L. Randall, Transcending Our Stories: A Narrative Perspective on Spirituality in Later Life, "Critical Social Work" 10:1 (2009), pp. 31-40. 
us a new and deeper meaning in life is spiritual." ${ }^{24}$ Not only are spirituality and narrative symbiotic in their relationship, as the stories from which narratives are constructed are structures of meaning, but many acknowledge that human narratives are integral to our sense of identity and self, they represent "a quest for personal meaning at deeper levels"25. Atkinson (1995) goes as far to state that telling and narrating our stories is in itself an "act of transcending the personal and entering into the realm of the sacred." ${ }^{26}$ Furthermore, whatever form our narrative expression takes, we experience spirituality not despite, but through the stories by which we understand our lives. As Randall (2009) reflects, "we do not meditate or pray, we do not make sense of sermons, we do not have mystical awakenings, in some sort of existential vacuum; rather, in the context of, or through the filter of, the complex set of storylines by which our sense of self is shaped." ${ }^{27}$

Brockelman (1992) explains how such storylines are in turn connected to and informed by the master narratives of our life philosophies that shape our worldview. ${ }^{28}$ Through such narratives we continuously interpret and re-interpret our reality, both personal and shared. ${ }^{29}$

In the context of such discourse, spirituality is understood as the human beings' search for purpose and meaning in life, that is both individual and open. It is a search for transcendental truth, including a sense of connectedness with others, nature and the divine. Spirituality can also facilitate greatly our journey beyond self towards feeling concerned and compassionate for other people..$^{30}$ In fact, many would agree that connectedness and meaning-making are two

${ }^{24}$ R. Atkinson, The gift of stories: Practical and spiritual implications of autobiography, life stories and personal mythmaking, Westport, C.T: Bergin \& Garvey 1995, p. xiii.

${ }^{25}$ E. Bianchi, Living with elder wisdom, in H.R.Moody (Ed.), Religion, spirituality and aging: A social work perspective, Binghamton, NY: Haworth Press 2005, p. 321.

${ }^{26}$ R. Atkinson, The gift of stories: Practical and spiritual implications of autobiography, life stories and personal mythmaking, Westport, C.T: Bergin \& Garvey 1995, p. 11.

${ }^{27}$ W.L. Randall, Transcending Our Stories: A Narrative Perspective on Spirituality in Later Life, "Critical Social Work" 10:1 (2009), p. 33.

${ }^{28}$ P. Brockelman, The inside story: A narrative approach to religious understanding and truth, Albany, NY 1992, State University of New York Press.

${ }^{29}$ D. McAdams, Power, intimacy and the life story: Personological inquiries into identity, New York 1988, Guilford, pp. 215-251.

${ }^{30}$ L.G. Underwood, J.A.Teresi, The daily spiritual esperience scale: Development, theoretical description, reliability, exploratory factor analysis, and preliminary construct validity using healthrelated data, "Annals of Behavioral Medicine" 24 (2002), pp. 22-33. 
of the most important components and motifs of spirituality that are embedded in human narratives, and implicit attitudes that they entail are those of respect, awareness and compassion. ${ }^{31}$

Thus, if such connectedness and meaning-making can be embedded in human narratives that are so rich with symbols, through critical reflection on one's past and present lives, and through imagination in a better future that transpires from a sense of hope, CRE can be a source for the transmission of God's revelation. It will also be argued that this could only be possible if the processes of reflection, (re-)interpretation and imagination CRE take off and are embedded in human experiences that flow out from the heart, are situated in a meaningful context facilitated by digital technologies, and occur in a community context marked by empathy, authenticity and compassion.

\section{Connecting CRE and Spirituality/Transcendence in Adolescence through the Power of the Human Narrative}

All throughout my teaching career I listened to, as empathically as possible, to so many stories that young people wanted and were willing to share either with me alone or even with their classmates. When stories were shared in class, in a community setting, rather than just on a personal level, their potential for stimulating minds, touching hearts and liberating souls was unlocked, and their power to foster a sense of empathy and compassion that brings about transformative healing, empowerment and resilience was unleashed. Thus, the following section will focus on the benefits that a narrative-hermeneutic-developmental approach brings to teaching and learning in the CRE classroom, especially in its immense potential to concretize the revelation of God in human lives and everyday life experiences. As will be seen, such an approach emerges out of an intersection and positive synergy between philosophy and developmental psychology, and simultaneously leads to its consolidation. Such a synergy is evident from a vast corpus of literature that developed over the last four decades, focusing on narrative identity in developmental and personality psychology. This, in turn, delivered a significant contribution not only to the academia but also

${ }^{31}$ D. Hay, R. Nye, The spirit of the child, London 2006, Jessica Kingsley Publishers; A. Bussing, A. Foller-Mancini, J. Gidley, P. Heusseur, Aspects of spirituality in adolescence, "International Journal of Children's Spirituality" 15:1 (2010), pp. 25-44. 
to a variety of disciplines under the umbrella of the humanities. Its main aim has always been to understand how individuals employ narratives to develop and sustain a sense of personal unity and purpose from diverse experiences across the lifespan. ${ }^{32}$ It interweaved significantly with clinical, developmental, and cognitive psychology, and forged links even with social psychology ${ }^{33}$, and other related social sciences like sociology and anthropology. ${ }^{34}$ It also found allies in philosophy ${ }^{35}$, psychoanalysis ${ }^{36}$, narrative therapy ${ }^{37}$ and literature. ${ }^{38}$

Even more importantly and significantly, is the strong relationship and direct correlation between the nurturing of spirituality (transcendence) through a narrative pedagogy, and young people's sense of well-being, extent of civic engagement and academic success, acquisition of coping skills, feelings of happiness, gratitude and positivity, level of self-awareness, empathy, forgiveness, purpose and meaning, a sense of a hopeful future and the ability for thriving and for peaceful resolution, as well as a strong degree of resilience, especially in the face of pain and adversities that can cause a multitude of negative emotions, and trigger off mental disorders. ${ }^{39}$ Thus, in the next section it will be argued that if CRE can shape its pedagogical trajectory through a narrative-hermeneuticaldevelopmental approach that emerges from, leads to, and nurtures a spiritual

32 D.P. McAdams, The psychology of life stories, "Review of General Psychology" 5 (2001), pp. 100-122.

${ }^{33}$ R.F. Baumeister, S.R. Wotman, A.M. Stillwell, Unrequited love: On heartbreak, anger, guilt, scriptlessness, and humiliation, "Journal of Personality and Social Psychology" 64 (1993), pp. 377-394.

${ }^{34}$ J.A. Singer, Narrative identity and meaning-making across the adult lifespan, "Journal of Personality" 72:3 (2004), pp. 437-459.

${ }^{35}$ P. Ricoeur, Time and narrative, Chicago 1984, University of Chicago Press (Translated by Kathleen McGlaughlin and David Pellauer).

${ }^{36}$ R. Schafer, Narration in the psychoanalytic dialogue, in: W.J.J. Mitchell (Ed.), On Narrative, Chicago 1981, University of Chicago Press, pp. 25-49; D.P. Spence, Narrative truth and historical truth: Meaning and interpretation in psychoanalysis, New York 1982, Norton.

${ }^{37}$ M. White, D. Epston, Narrative means to therapeutic ends, New York 1990, Norton.

${ }^{38}$ B. Lau, Wordsworth's The Prelude and self-defining memories, in: L.H.Peer (Ed.), Recent perspectives on European romanticism, Lewiston M.E 2002, The Edwin Mellon Press, pp. 93-103; J.S. Bruner, S. Wiesser, The invention of self: Autobiography and its forms, in: D.R. Olsen, N. Torrance (Eds.), Literacy and orality, New York 1991, Cambridge University Press, pp. 129-148.

${ }^{39}$ P.C. Scales, A.K. Syvertsen, P.L. Benson, E.C. Roehlkepartain, A. Sesma, Relation of Spiritual Development to Youth Health and Well-Being: Evidence from a Global Study, 2014, DOI: 10.1007/978-90-481-9063-8_41. 
hunger that is universal, the curricular subject could become a vehicle for God's revelation, personally and communally, as well as a source of holistic wellbeing. Moreover, for the Catholic teacher, the latter does not occur independently, but as a consequence of the former. It will be also explained how this approach to narrative learning could be interwoven from Paul Ricoeur's and Charles Taylor's philosophies, and Robert Kegan's perspective on psychological development combined with social construction. Brought together, these can create a conducive space for God's revelation to occur and to be concretely experienced by students. Such an approach can be effectively implemented through the power of human stories that are shared in a community context through the potential, creativity, appeal and engagement of digital technologies.

Moreover, this paper focuses mainly on the age of adolescence in relation to the exploration of the connection between CRE and spirituality/transcendence through the power of human narrative. This is due to the fact that many research studies conducted over the last five decades or so accord adolescence and early adulthood special significance for the development of self and identity $^{40}$, autobiographical memory ${ }^{41}$, and narrative identity ${ }^{42}$. A significant number of studies in the area of narrative development and learning suggest that the encoding of autobiographical memories, which in narrative terms constitute the stuff of which selves are made, occurs mainly from adolescence onwards ${ }^{43}$. During this period of development, adolescents acquire the abilities of providing self-descriptions that are increasingly multifaceted and intricate ${ }^{44}$, and also for recognizing contradictions in the self and resolving them ${ }^{45}$. Adolescents

${ }^{40}$ J.J. Arnett, Emerging adulthood: A theory of development from the late teens through the twenties, "American Psychologist" 55 (2000), pp. 469-480; J. Kroger, Identity development during adolescence, in: G.R. Adams, M.D. Berzonsky (Eds), Blackwell handbook of adolescence, Malden MA 2003, Blackwell, pp. 205-226.

${ }^{41}$ A. Holmes, M.A. Conway, Generation identity and the reminiscence bump: Memory for public and private events, "Journal of Adult Development" 6 (1999), pp. 21-34.

${ }^{42}$ K.C. McLean, Late adolescent identity development: Narrative meaning making and memory telling, "Developmental Psychology" 41 (2005), pp. 683-691.

${ }^{43}$ M. Pasupathi, T. Hoyt, The Development of Narrative Identity in Late Adolescence and Emergent Adulthood: The Continued Importance of Listeners, "Developmental Psychology" 45:2 (2009), pp. 558-574.

${ }^{44}$ A.R. Sutin, W.R. Robins, Continuity and correlates of emotions and motives in self-defining memories, "Journal of Personality" 73 (2005), pp. 793-824.

${ }^{45}$ S. Harter, A. Monsour, Developmental analysis of conflict caused by opposing attributes in the adolescent self-portrait, "Developmental Psychology" 28 (1992), pp. 251-260. 
also develop more cognitive and epistemic abilities ${ }^{46}$, and the dynamic of the relationship between their narrative learning abilities and their identity development becomes increasingly affected by peer relationships and exposure to higher educational opportunities and socio-political contexts ${ }^{47}$.

\section{A Narrative-Hermeneutic-Developmental Approach to Learning and Reflection in CRE: Ricoeur, Taylor and Kagan in Dialogue}

Paul Ricoeur is considered by many other prominent thinkers to be one of the foremost proponents in philosophy for his in-depth analysis of the inherent correlation between narrative and lived experience. Many agree that this is the basis for understanding identity as narrative ${ }^{48}$. Ricoeur reflects deeply on why he believes that stories are the best vehicles known to human beings for conveying how and why a human agent, endowed with consciousness and motivated by intention, enacts desires and strives for goals over time. ${ }^{49}$ Through stories people make sense out of life and such a meaning-making process is common to all people across various times and cultures.

\subsection{Ricoeur and the Correlation between Narrative and Lived Experience}

Then, in Oneself as Another, he elaborates further on the correlation between narrative and lived experience, by stating that human beings learn how to understand themselves and even shape a worldview in terms of stories..$^{50}$ In this way Ricoeur shows that identity formation is such an important and significant

${ }^{46}$ K.S. Kitchener, C.L. Lynch, K.W. Fischer, P.K. Wood, Developmental range of reflective judgment: The effect of contextual support and practice on developmental stage, "Developmental Psychology" 29 (1993), pp. 893-906.

${ }^{47}$ E.C. Hair, K.A. Moore, S.B. Garrett, T. Ling, K. Cleveland, The continued importance of quality parent-adolescent realtionships during late adolescence, "Journal of Research on Adolescence" 18 (2008), pp. 187-199.

${ }^{48}$ J.H. Lunde-Whitler, Paul Ricoeur and Robert Kegan in Unlikely Dialogue: Towards A "Narrative-Developmental" Approach to Human Identity and Its Value for Christian Religious Education, "International Journal of Practical Theology" 19:2 (2015), DOI: https://doi. org/10.1515/ijpt-2014-9001.

${ }^{49}$ P. Ricoeur, Time and Narrative I, Chicago 1984, The University of Chicago Press.

${ }^{50}$ P. Ricoeur,Oneself as Another, Chicago 1992, The University of Chicago Press. 
developmental task that takes place over the whole span of one's lifetime. His philosophy takes to task both the question of permanence in time related to the past and present, the 'idem-identity' of the individual, and also the question of selfhood, that relates permanence in time to the future, the individual's 'ipseidentity. The former strives to understand how a person can experience continuity in the life story, and see oneself as the same person despite the various roles one assumes over the lifetime. On the other hand, the latter's concern is intrinsically related to the fundamental question of selfhood, i.e. who am I? This question goes beyond that of sameness, because it is not only addressed to the past but also to the future. It is also intrinsically connected to another human fundamental question, namely 'who will I be in the future'? According to the French philosopher, answers to such questions always stem out of interpretive meaningful acts, such as the act of promising, which manifests 'faithfulness' to one's self, of keeping one's word, thus emphasizing that identity can never be reduced to sameness. Ricoeur makes it very clear that in order to answer such basic questions, it is necessary to construct an autobiography, to tell one's life story. ${ }^{51}$ This could be done by discerning the plot in one's life, and thus acquiring the meaning, continuity and coherence that it imposes on life experiences: "expected and unexpected, important and trivial, desired and undesired." ${ }^{2}$ Ricoeur reflects deeply on how identity development is facilitated when individuals become narrators of their own life story, in which they are the main character. ${ }^{53}$ The plot is partly determined by the events that occur over the course of one's life, but also by the continuous interpretation of these events that leads to a new narrative configuration.

Another principal characteristic of Ricoeur is that he manages to demonstrate how narrative identity always mediates between two extremes: harmony and dissonance, lived and told, innovation and sedimentation, fact and fiction, "what is" and "what ought to be", voluntary and involuntary, the Cartesian cogitophilosophy that emphasizes the exalted cogito and the Nietzschean philosophy of the "shattered cogito", the author and the reader. In this way Ricoeur manages to reconcile the same categories which the famous empiricist British philosopher

${ }^{51}$ P. Ricoeur, Life in Quest of Narrative, in: D. Wood (Ed.), On Paul Ricoeur: narrative and interpretation, London and New York 1991, Routledge, pp. 20-33.

${ }^{52}$ P. Vermeer, J. Van der Ven, Religious Identity Formation: An Educational Approach, "International Journal of Education and Religion" 2 (2), p. 109.

${ }^{53}$ P. Ricoeur, Oneself as Another, Chicago 1992, The University of Chicago Press. 
John Locke took as contraries. Doing so, he also shows how "a narrative understanding of human identity and meaning-making is inherently equipped to contend with a complex and non-reductionistic understanding of identity." ${ }^{34}$ Thus, over the whole course of one's life, both conscious and subconscious narratives accumulate, and relate to our sense of identity to varying degrees.

This perspective on how our narrative identity develops considers the importance of both observable and non-observable narrative characteristics of our thoughts and feelings. It shows that while we do not internalize everything we observe, what is captured by and stored in our memory exceeds by far what we have awareness of at any given moment. Moreover, it also believes that our subconscious memories, even if inaccessible, significantly affect our actions, judgments, emotions and self-understanding. This process occurs in very subtle but powerful ways, and corresponds to what Michael Polanyi refers to as 'tacit knowledge. 55 Such a process is concerned with 'internalization' as much as it also embraces an inherently social and dialectical view of learning, as narrative only becomes possible through exchange and reciprocity in relationships with others. ${ }^{56}$ In this broad and far-reaching perspective of narrative identity, personal agency is of utmost importance in the development of identity formation, since the conscious expression of our life stories acquires a significant role in the process of meaning-making. This conscious expression helps us discern and even articulate a sense of both location and purpose in the world. In this way, even though our life stories remain embedded in a certain level of inevitable ambiguity, we still exercise agency that imposes meaning to our experiences. However, this personal agency only operates within the parameters established by prior-existing conscious and subconscious narrative materials of people and communities with a given (situated) context. This is referred to by Ricoeur himself as the "pre-understanding of the world of action, its meaningful structures, its symbolic resources, and its temporal character". ${ }^{57}$ Through such a dynamic Ricoeur explains how every human being has the possibility of answering the

${ }^{54}$ J.H. Lunde-Whitler, Paul Ricoeur and Robert Kegan in Unlikely Dialogue: Towards A "Narrative-Developmental" Approach to Human Identity and Its Value for Christian Religious Education, "International Journal of Practical Theology" 19:2 (2015), p. 295: DOI: https://doi. org/10.1515/ijpt-2014-9001.

${ }^{55}$ M. Polanyi, The Study of Man, Chicago 1964, University of Chicago Press, p. 88.

${ }^{56}$ P. Ricoeur, Oneself as Another, Chicago 1992, The University of Chicago Press, pp. 163 168, 171-202.

${ }^{57}$ P. Ricoeur, Time and Narrative I, Chicago 1984, The University of Chicago Press, p. 54. 
most fundamental question 'who am?' at any given moment in time, something that occurs as a continuous, never-ending fluid process through future tellings and writings, as well as by listening to other narrate our lives back to us. In this way we redefine ourselves continuously over time through an ongoing dialectical relationship with other people from all possible walks of life, communities, contexts, observations and experiences. ${ }^{58}$

Ricoeur's hermeneutical cycle that lies at the heart of his narrative theory, and that views one's consciousness as an act of mediation between the experiencing of life ('text' to be read) and the multiplicity of internalized historical narratives ('context'), out of which stories flow with meaningful connection, understands the process of identity formation as dynamic and in constant evolution. However, the act itself of articulating lived experience through life-stories also provides stability and constancy to identity. This concept is also reflected and elaborated upon by Donald E. Polkinghorne (1988), a professor of counselling and a practicing psychotherapist, who maintains that identity is not a substance but an 'activity' that continuously gathers up and gives shape to our scattered actions and makes them significant. In his book Narrative Knowing and the Human Sciences, he writes that a person's own narrative understanding of his or her life causes the behaviour expressive of that intimate story, and therefore scientists must learn to read people as they would a text. He states that "acting is like writing a story, and the understanding of action is like arriving at an interpretation of a story." 59 It would be a mistake, he thinks, to try to explain human behaviour by using general laws, whether these be physical, biological, psychological, or social laws, since "bodily movement is 'caused' by the meaning to be expressed."

Ricoeur uses the term 'emplotment' to explain how identity develops in meaningful ways through the dynamic process of story-telling which acts on existing material, modifying and expanding it to create more narratives that include a certain extent of novelty. For stories to have a real impact on one's present, they must correspond to what a person already knows and understands through previously internalized stories. The unique power of stories, according

${ }^{58}$ P. Ricoeur, Oneself as Another, Chicago 1992, The University of Chicago Press, pp. 115-125.

${ }^{59}$ D.E. Polkinghorne, Narrative Knowing and the Human Sciences, State University of New York Press 1988, New York NY, p. 142.

${ }^{60}$ D.E. Polkinghorne, Narrative Knowing and the Human Sciences, State University of New York Press 1988, New York NY, p. 142. 
to Ricoeur (1984) lies in their 'double allegiance' to both intelligibility and innovation, the strange and the familiar, life 'as' and life 'as if. ${ }^{61}$ Thus, when persons recount and retell their past, they are not simply remembering and reciting life-histories and chronologies of past events, but they are reflecting deeply on the significance of life occurrences, through the discernment of a dynamic plot, which has the potential of being interpreted in a multitude of ways, and which can invoke known themes, values, characters, etc. In this way, reflection on life-stories and experiences helps us connect past events with the present, and at the same time provides better self-understanding by way of which we can imagine alternative and possible personal narratives unfolding in the future. The lived present, thus, becomes a way to rediscover our capacity to imagine constructively our life as other than it is. ${ }^{62}$

Ricoeur was greatly influenced by the philosopher Aristotle, an influence that helped him formulate his theory of 'mimesis', through which he could offer insights on narrative identity development and learning that go well beyond the mere concepts of 'assimilation' and 'accommodation' proposed by the Swiss clinical psychologist and researcher in child development Jean Piaget. According to Ricoeur, the act of narrating can be described as an act of mimesis-praxeos that is a creative imitation of action. This is at the same time an act of 'poeisis' as imagination and creativity are both engaged through the plot ('muthos'). ${ }^{63}$ This human capacity is also mentioned and explained by Ricoeur in his studies on hermeneutics and the human sciences: "The activity of narrating does not consist simply in adding episodes to one another; it constructs meaningful totalities out of scattered events. The art of narrating, as well as the corresponding art of following a story, therefore requires we are able to extract a configuration from a sequence." ${ }^{\prime 4}$

Thus, the process of 'mimesis-poiesis', according to Ricoeur, becomes the means by which self-constituting stories, shared through a multiplicity of one's social relations, both represent reality and at the same time reconstruct and

${ }^{61}$ P. Ricoeur, Time and Narrative I, Chicago 1984, The University of Chicago Press.

${ }^{62}$ A. Nelson, Imagining and critical reflection in autobiography: An odd couple in adult transformative learning, "Adult Education Research Conference", Paper 33 (June 30, 1997), accessed at http://newprairiepress.org/aerc/1997/papers/33 (16.11.2020).

${ }^{63}$ P. Ricoeur, Time and Narrative I, Chicago 1990, The University of Chicago Press.

${ }^{64}$ P. Ricoeur, Hermeneutics and the human sciences(17th edn.), J. B. Thompson (Trans., Ed.), Cambridge, MA 2005, Cambridge University Press, p. 278. 
re-interpret it in new ways. ${ }^{65}$ A configuration comes out of the elements that make up one's life narrative/s through the presence of connections and relationships among them, by way of which active thinking is provoked and meaning construction is supported. ${ }^{66}$ In this way, our most significant life-stories become powerful 'imitative creations' all throughout out life span, and provide us with a sense of wholeness, as well as purpose and hope that are so crucial for human beings to live meaningful lives. Such a perspective sheds light on how narrative and autobiographical learning occur at three different levels: when we hear stories such as myths, moral tales, religious parables and personal experiences, when we tell the stories ourselves and thus become the actor, putting all the details together and making the experience coherent for ourselves and others, and thirdly when we recognize the narratives in which we are positioned. Clark states that "this type of learning is critical and even emancipatory. It presumes that our thinking is shaped by socio-cultural forces; recognizing our narrative situatedness enables us to identify and critique how that shaping takes place." ${ }^{37}$ At all these levels of narrative learning, meaning is simultaneously related to past experience, re-constructed within the present, and more often than not oriented towards the future. Moreover, and most of all, the process of mimesis-poiesis, that lies at the heart of Ricoeur's narrative dialectical hermeneutics, demonstrates and opens up new possibilities for examining both the 'social-communal' and the 'psychological-personal dimensions' of learning, as well as the intimate and intricate relationship between them.

\subsection{Charles Taylor and the Moral Dimension of Narrative Interpretation}

The contemporary, Canadian philosopher Charles Taylor describes identity as "who we are" and "where we are coming from". He understands it as "the background against which our tastes and desires and opinions and aspirations

${ }^{65}$ J.H. Lunde-Whitler, Paul Ricoeur and Robert Kegan in Unlikely Dialogue: Towards A "Narrative-Developmental" Approach to Human Identity and Its Value for Christian Religious Education, "International Journal of Practical Theology" 19:2 (2015), DOI: https://doi. org/10.1515/ijpt-2014-9001.

${ }^{66}$ G. Dettori, A. Paiva, Narrative Learning in Technology-Enhanced Environments, in: N. Balacheff et al. (Eds.), “Technology-Enhanced Learning: Principles and Products” (2009), pp. 55-69, DOI: 10.1007/978-1-4020-9827-7_4.

${ }^{67}$ M.C. Clark, Narrative Learning: Its Contours and Its Possibilities, "New Directions for Adult and Continuing Education" (2010), p. 6. 
make sense. ${ }^{38}$ Moreover, Taylor believes that this background is formed through identity formation that occurs within the dynamic of our narrative selves. For him the 'self' is a life project that revolves around the interrelationships between self, identity, and learning. In Sources of the Self, he views this project in terms of life as a whole as explicitly states that "in order to have a sense of who we are, we have to have a notion of how we have become and of where we are going." ${ }^{69}$ Making sense of ourselves necessarily requires an active and reflective engagement with our identity, and when one has opportunities to narrate the life story through its experiences, this process is greatly facilitated.

Moreover, Taylor considers that the inter-subjective/social/relational and moral dimensions in our narrative learning that is so pivotal in the construction of our 'selves', are crucially important and absolutely necessary. Taylor's perspective is significantly dependent upon the recognition that each individual is a "self only among other selves" ", "a self among interlocutors" a self that exists within "webs of interlocution"73 that also requires a language. Identity could only be constructed "through a language of interpretation"74 that is always formed in exchange with the significant others, the people who really matter to us and who deeply impact and shape our lives. All throughout our life span, such people, whether physically present or not, always act as "interlocutors who are essential to me achieving my self-definition and who are now critical to my continuing grasp of language of self-understanding, and my relationship to both can overlap." 75 In this sense, Taylor uses the word 'language'

${ }^{68}$ C. Taylor, Multiculturalism: Examining The Politics of Recognition, New Jersey 1994, Princeton University Press, p. 33.

${ }^{69}$ C. Taylor, Sources of the Self: The Making of Modern Identity, Cambridge, MA 1989, Harvard University Press, p. 47.

${ }^{70}$ C. Taylor, Sources of the Self: The Making of Modern Identity, Cambridge, MA 1989, Harvard University Press, p. 35.

${ }^{71}$ C. Taylor, Sources of the Self: The Making of Modern Identity, Cambridge, MA 1989, Harvard University Press, p. 29.

72 C. Taylor, Philosophical Arguments, Cambridge, MA 1995, Harvard University Press, p. 230.

${ }^{3}$ C. Taylor, Sources of the Self: The Making of Modern Identity, Cambridge, MA 1989, Harvard University Press, p. 36.

${ }^{74}$ C. Taylor, Sources of the Self: The Making of Modern Identity, Cambridge, MA 1989, Harvard University Press, p. 34.

75 C. Taylor, Sources of the Self: The Making of Modern Identity, Cambridge, MA 1989, Harvard University Press, p. 36. 
to refer not only to the words that we articulate verbally, but even more so, to the language of norms, gestures, age, community, tradition, and culture, with all the elements embedded in it. These are also modes of strong evaluation, according to Taylor, through which we become fully human agents, understand ourselves, define, redefine and discover our identity. ${ }^{76}$

Finally, but certainly not the least important, is the fact that Charles Taylor believes that the coordinates of self-identity are fundamentally moral. In the continuous process of learning about one's self and the world around us, leading to identity formation, there is a 'moral space' that is so fundamental. In Taylor's own words, "to know who you are is to be oriented in moral space, a space in which questions arise about what is good or bad, what is worth doing and what not, what has meaning and importance for you and what is trivial and secondary."77 Thus, for Taylor, the hermeneutics that defines and forms human identity is both narrative and moral in nature. This is due to the fact that the construction of 'self' entails a temporal (lifelong) project of "life as a whole" in terms of consistent life purposes, and at the same time rests on the ongoing discovery of the strongly valued meanings of one's identity and life experiences through the articulation of the person's moral assumptions.

\subsection{Embedding a Constructive-Developmental Perspective in Narrative} Learning and Teaching for Transformation: The Contribution of Robert Kegan Robert Kegan, an influential American psychologist, has developed a constructive-developmental theory, so called because it is concerned with both the construction of an individual's understanding of reality and the development of that construction to more complex levels over time. In it he proposes five distinct stages, or better still as he refers to them, 'orders of the mind', through which 'transformation' occurs as people progress to qualitatively different stages of meaning-making. Although new information may add to the things a person knows, this transformational learning is not simply learning new information or skills, but it changes the way a person can know those things. According to Kegan, this is transformation that changes the very form and essence of the

${ }^{76}$ K. Zhao, G. Biesta, The Moral Dimension of Lifelong Learning: Giddens, Taylor, and the "Reflexive Project of the Self", "Adult Education Quarterly" 62:4 (2012), pp. 332-350.

77 C. Taylor, Sources of the Self: The Making of Modern Identity, Cambridge, MA 1989, Harvard University Press, p. 28. 
meaning-making system - it makes more complex but at the same time more capable of dealing with multiple demands and uncertainty that are so much part of the fabric of the postmodern world and culture. ${ }^{78}$ In this constructive-developmental approach, transformative learning always results when an individual is able to step back and reflect on something. Thus, for Kegan, transformative learning happens when someone changes, "not just the way he behaves, not just the way he feels, but the way he knows - not just what he knows but the way he knows." ${ }^{79}$

Transformational learning, in view of Kegan's theory, always depends on the crucially important distinction between that which is Subject and that which is Object. As Kegan himself makes so clear, "we have object; we are subject." Things that are Subject cannot be named, and therefore could not be reflected upon, since such reflection necessarily requires the ability to stand back and look at things from a distance to see them as they are. Kegan states that "we cannot be responsible for, in control of, or reflect upon that which is subject." ${ }^{\text {1 }}$ We hold as Subject all our unquestioned beliefs and assumptions about the world. On the other hand, things that are Object in our lives are "those elements of our knowing or organizing that we can reflect on, handle, look at, be responsible for, relate to each other, take control of, internalize, assimilate, or otherwise operate upon." ${ }^{82}$ Moreover, because of this we can tell that "the element of knowing [when it is Object] is not the whole of us; it is distinct enough from us that we can do something with it." ${ }^{33}$

While it is true to say that the a significantly large part of the life of every individual being is taken up by the Subject, Kegan is most interested in that part of development that involves the move of elements from Subject to Object.

${ }^{78}$ J.G. Berger, Exploring the connection between teacher education practice and adult development theory. "Doctoral dissertation" (2002), Harvard University.

${ }^{79}$ R. Kegan, In over our heads: The mental demands of modern life, Cambridge, MA 1994, Harvard University Press, p. 17.

${ }^{80}$ R. Kegan, In over our heads: The mental demands of modern life, Cambridge, MA 1994, Harvard University Press, p. 32.

${ }^{81}$ R. Kegan, In over our heads: The mental demands of modern life, Cambridge, MA 1994, Harvard University Press, p. 32.

${ }^{82}$ R. Kegan, In over our heads: The mental demands of modern life, Cambridge, MA 1994, Harvard University Press, p. 32.

${ }^{83}$ R. Kegan, In over our heads: The mental demands of modern life, Cambridge, MA 1994, Harvard University Press, p. 32. 
As more complex elements gradually become Object, the world view becomes more intricate as we would be able to see and act upon more elements. Gradually, Kegan believes that a shift of entire meaning-making systems occurs from Subject to Object, and out of such a shift his five 'orders of mind' stem. These orders of mind involve qualitatively different ways of constructing reality and each is a qualitative shift in meaning making and complexity from the one before it. Kegan maintains that we build upon what we have learned in a previous order by moving elements of the earlier meaning-making system from Subject to Object. This process frees us from a situation where we were controlled to one in which we gained a new sense of control over the meaning-making system itself and, in the process, we transform the actual form of our view and understanding of the world. In this way, Kegan manages to unite social construction and psychological development together. Through such an approach he believes that people could be freed: “...from a static view of phenomena ... shifting our thinking - from entity to process, from static to dynamic, from dichotomous to dialectical' to contend more with not only ... the shape and sequence of our various consolidations of meaning, but to the universal processes themselves of constructing .... a meaning." ${ }^{\prime 4}$

This view developed and proposed by Kegan sees knowledge and wisdom that accumulate over the years and become increasingly intricate, as constitutes of subjects and objects together. These are, as Lunde-Whitler (2015) explains: "....derived from multivariate past experiences and encoded within the mind, which both exert influence on our present and future experiences. The difference between the two is that ,objects' as they are interpreted can be re-worked and re-coded, whereas , subjects' can only be interpreted as immediate impressions." ${ }^{\prime 5}$ As we learn how to transform subjects into objects, a whole new world of subjectivities opens for us, and we experience true learning in the form of leaps to higher orders of consciousness.

${ }^{84}$ R. Kegan, In over our heads: The mental demands of modern life, Cambridge, MA 1994, Harvard University Press, p. 12.

${ }^{85}$ J.H. Lunde-Whitler, Paul Ricoeur and Robert Kegan in Unlikely Dialogue: Towards A "Narrative-Developmental" Approach to Human Identity and Its Value for Christian Religious Education, "International Journal of Practical Theology" 19:2 (2015), p. 302, DOI: https://doi. org/10.1515/ijpt-2014-9001. 


\subsection{Connecting Ricoeur, Taylor and Kegan}

for a Narrative-Hermeneutical-Developmental Perspective:

Ideal Space for Revelation to Effect Transformation

When Paul Ricoeur, Charles Taylor and Robert Kegan are brought into dialogue, through their narrative-hermeneutical and constructive-developmental approaches to human identity and learning, they offer a huge potential to understand the dialectical, dynamic and intricate manner which characterizes the gradual development of consciousness through its ongoing transformation into new subject-object relationships. This occurs precisely through the process of mimesis-poiesis proposed by Ricoeur that is endemic to narratives, which in their very nature as 'imitative creations' make it possible for the individual to combine imagination with what can be grasped as object (mimesis), and by doing so, stretch the limits of knowledge. The process of mimesis-poiesis can be applied to all of the three consciousness-types, i.e. pre-narrative, narrative and meta-narrative, which in a way, using Kegan's term, represent qualitative leaps.

These three approaches can come together, enrich the concept of transformative learning and show how it can occur in the context of everyday life. They can manifest how the construction of the life story can interact with the author's transformative learning. This is due to the potential of narrative learning to alter and/or modify the learner's self-understanding, worldviews and ways of being in the world. ${ }^{86}$ The process of mimesis-poiesis and the gradual shift of subjects into objects are at the heart of narrative learning, and through imagination and critical thinking, they make learning from experience not only possible but a continuous process throughout all the life stages, one that sustains the ongoing formation and reinvention of the narratives of life.

Such a dynamic also reveals the close connections that exist between narrative and transformational learning. The latter was proposed as a learning theory by Jack Mezirow since the late 1970s. Through it, Mezirow proposed that adults could gain awareness of the distorted and incomplete assumptions that lie at the heart of a system of habits of the mind through which they interpret reality. For him, therefore, learning should essentially lead to a critical re-evaluation of people's assumptions and transform them, giving vital meaning

\footnotetext{
A. Nelson, Imagining and critical reflection in autobiography: An odd couple in adult transformative learning, "Adult Education Research Conference", Paper 33 (June 30, 1997), accessed at http://newprairiepress.org/aerc/1997/papers/33.
} 
to their experiences. ${ }^{87}$ Kokkos gives a concise explanation of Mezirow's four types of learning, which occur gradually and in a linear manner, and which eventually lead to an epistemological as well as an ontological transformation. "The first type involves the elaboration of an existing point of view. It is a process during which we improve or change a specific assumption we have embraced, without questioning the broader system of our mental habits in which this assumption is embedded. The second type of learning refers to adopting a new point of view, which is nevertheless compatible and consistent with those that have been already embraced. Therefore, it is a process in which we gain more information, but without transforming our way of making sense. The third type of learning constitutes a radical transformation of a point of view, while the fourth type is the transformation of one or more habits of mind. In the latter, we transform not only what we know, but also the way in which we perceive reality and learn from our experiences." 88

The following section will present reflections on some of the results of a three-year empirical study, embedded in the professional practice of CRE in Malta. This study sought to put into practice the narrative-hermeneuticaldevelopmental approach discussed above, thus enriching the religious educators' understanding of how God's revelation could be experienced and not just comprehended by students. Furthermore, this real experience of revelation in students' lives, made possible through the processes of meaning-making and interpretation applied to human stories constructed into narratives. This endeavour would also incorporate elements from all models of revelation as exposed by Dulles, and enflesh the more holistic symbolic model, enlightened and inspired by a Rahnerian perspective of God's Spirit dwelling in the human heart, planting the seeds of hope and resilience, through empathy and compassion found in community.

${ }^{87}$ J. Mezirow, Fostering Critical Reflection in Adulthood, San Francisco, CA 1990, JosseyBass; J. Mezirow, Transformative Dimensions of Adult Learning, San Francisco, CA 1991, JosseyBass; J. Mezirow, Transformative Learning: Theory to Practice. New Directions for adult and Continuing Education, 74 (Summer 1997), pp. 5-11.

${ }^{88}$ A. Kokkos, The process of transformation: Kegan's view through the lens of a film by Wenders. Paper presented during conference titled "What's the point of Transformative Learning", Athens 2014, Proceedings, pp. 106-107. 


\section{A 3-year Empirical Study}

More than three years ago I decided to embark upon a research journey through which I combine my interests in CRE, MLE, Psychology and Philosophy.

\subsection{Aims of Study}

The main aim of this research study was to explore ways how God's revelation can be concretely experienced by adolescents through the reflection on and sharing of their narratives in the context of CRE, and facilitated by digital creative technologies. To achieve such an aim, the study also investigated the effectiveness of a pedagogy for CRE, that starts from the human experiences of adolescents, is based on empathy, unconditional love and compassion, and is illuminated by divine pedagogy, especially that revealed through Jesus Christ in the Gospel.

\subsection{Research Design}

This three-year research study adopted a multimodal ethnographic approach in the collection of data. Through such an approach traditional ethnographic tools and strategies of data collection, namely focus groups, semi-structured in-depth interviews and participant observation, were combined with more creative multimodal modes of expression that could also be a valuable source of data that facilitates the understanding of the adolescent transcendental realm throughout their identity formation. The latter included photographs taken of the students engaged in their activities, video recordings of segments of the two focus group research seminars, the students' mood boards and story-boards produced in the planning stage of their multimodal productions, voluntary reflections by the student participants taken from their reflective journals, and the participants' multimodal productions.

\subsection{Procedure}

Two research seminars were organized for each group of participants, comprised of students from one class, who were accompanied by a teacher or two, and in some cases by an LSE who was responsible for a student/s with special needs. During the first seminar that took place at the production house Cam Productions International (CPI) they were toured round the place, given 
the opportunity to observe and satisfy their lure for media technologies with so much creative potential. Then they were taken to a production studio where the seminar was held. In it they were given the task - a short multimodal production in which they express creatively their perspective on and understanding of the value of their faith, or lack of it. They were also shown the benefits of doing this by sharing some of their life experiences that had shaped their perspective on their faith. It was also explained to the students that in the process of working on their presentations, they would be assisted by their MLE or DA teacher in class, while they learn the necessary skills of production embedded in their syllabi. They would also have the opportunity to reflect on their work all throughout the process, with the aid of a reflective journal.

During the second seminar, then, which took place around a month after the first, the student participants from one class spent a school day together in a place outside their school environment, and they shared their multimodal presentations. Being simultaneously the researcher and the seminar's facilitator, my main role was to facilitate the sharing of life experiences and reflection upon them by the student participants, and at the same time exploring how various learning outcomes of several aspects and elements of CRE could be addressed through such reflection. Moreover, I also sought to investigate how these same aspects and elements of CRE could possibly serve as a source of enlightenment, empowerment, resilience and healing in the fragmented lives of adolescent students.

\subsection{Sample}

For this study a simultaneously purposive and convenient sample of eight-five students from Maltese secondary Church schools $(\mathrm{N}=85)$ was selected. Of these, 78 were Maltese, and 7 were foreigners. Gender wise, there were 43 were girls and 42 boys. One-to-one semi-structured in-depth interviews were conducted with 33 of these participants, of whom 21 were girls and 11 were boys. All the student participants had CRE as a compulsory curricular subject, as well as MLE and/or Digital Arts (DA) as optional subjects they followed. Few other students who voluntarily asked to be part of the sample, had followed other short courses related to the creative media. These were courses in photography, film-making, as well as in software programmes that provide opportunities for learning the use of photo and video editing tools and techniques. 


\subsection{Results, Interpretation and Analysis}

After all audio-recorded seminar (including focus groups) inputs and discussions, as well as in depth interviews, were transcribed, thematic analysis was combined with a narrative analysis of the participants' life experiences. Such analysis was done in the context and process of applying Ricoeur's method of interpretation that occurs in stages, namely: distanciation, appropriation, explanation and interpretation. ${ }^{89}$ In this way transcendental reflection on the life narrative was understood and processed through a narrative-phenomenologicalhermeneutic perspective with the inclusion of the psychological dimension of human narrativity. Thus, such an analysis had significant potential to enhance the narrative-hermeneutic-developmental approach to learning, and explore various pedagogical implications for the holistic education of adolescents, especially in and through CRE. A small group was responsible for this analytical and interpretative process that led to a number of general categories and related themes that emerged from the data. The group was made up of myself as the main researcher, and four other persons, three teachers and one LSE, who had all been part of the project with their students. A consensus was then reached on the most prevalent themes that we had to start focusing on, in the spirit of Consensual Qualitative Research (CQR). Each one of these (outlined and discussed below) was further sub-divided into other themes that came across clearly through words, phrases and/or expressions that were used frequently and/ or interpreted by the participants in similar ways, to imply the same or similar meaning/s.

\subsubsection{Faith and Transcendence}

It was clearly evident from data gathered from both interviews and the focus group seminars that all the students feel the need to reach beyond themselves and serve something greater. In various ways they seem to be engaged in meaning-seeking and meaning-making processes that are closely related to reflection upon their past and present life, and which are a source of empowerment through a sense of hope for the future. Many of them feel that through the right attitude and perspective on life, and through reflection on their past experiences, they could learn how to aspire for a better future

${ }^{89}$ P. Ricoeur, Hermeneutics and the Human Sciences: Essays on Language, action and interpretation, trans. By J. B. Thompson, New York 1981, Cambridge University Press. 
that would fulfil their dreams, actualizing their potential for themselves and others. Moreover, the belief in a higher power and/or supreme being who has a personal plan for each and every human being, and who is willing to provide guidance along the journey that leads to this plan's accomplishment, encourages and empowers many adolescents to keep on searching meaning, even and especially in the face of adversity and affliction. These ideas and beliefs were interwoven in the students' comments, as can be seen in the following expressions: "I do believe in some kind of God or higher power that has the power of guiding my life and providing it with various options even in the face of tragedies... If God did not exist, or at least some kind of Supreme Being, how could human life have sense and meaning? Even our need to talk about God and discuss his existence or non-existence and their implications to our life.....that says a lot I think...."

Viktor Frankl understood self-transcendence as the hallmark of spirituality and as the end state of becoming fully human, and spoke of three different levels at which self-transcendence is manifested in everyday life, namely the seeking of ultimate meaning, the seeking of situational meaning, and the seeking of one's calling beyond self-actualization. All these were evident in the data analysed for this study, and can be represented by the following deep reflection made by a student during an interview: "I keep on believing in God even in very difficult circumstances and moments of pain and suffering that life seems to inevitably have in store for me, because He guides me and opens my eyes in taking important decisions through which I feel empowered in hope for a better life... that can give me the real happiness I always craved for...”

\subsubsection{Faith as a 'Lens' through which Life is Interpreted: the Need for 'Metaphors'}

A detailed study of and profound reflection on the students' metaphors for their life and faith, that were even captured by their cameras, certainly helped them experience life on a deeper level. Metaphor seemed to help the adolescent participants compare life to relatively more concrete and structured concepts, considering that life's meaning can be difficult to grasp and the experiences that comprise it not easy to interpret in a positive way that empowers one to move forward with hope. Metaphors through the camera helped them to simultaneously engage more their imagination and critical sense of reflection on life experiences, and filter their meaning through the students' religious beliefs and 
worldviews. Thus, the study pointed to the metaphor's potential to give relevance to and shed light on the relationship between the participants' religious creed and everyday life. "Faith is like a seed. It's planted and grows if it is watered and taken good care of. And the more it grows the more you will always find it useful in times of challenge and turmoil... I chose the flower because like our life it starts from a seed and just like our life it grows gradually while we continue to live through difficult experiences. In the same way that the flower grows... getting what it needs from the sun and nature, we also strengthen our faith as we go through different experiences in life."

\subsubsection{Faith in Relation to Personal Relationships and Attachments}

This study has clearly brought out the need for positive and secure attachment that these young people have. They spoke both of their attachments with animal pets and with people, especially parents, relatives and peers. Reflecting on these attachments in their memory seems to facilitate their path to transcendental reflection on spiritual and religious realities, such as the finitude of human life, the significance of death in the human journey of life, the meaning of negative life events that cause much pain to the human heart, and the potential learning and empowerment for the future through imagination that could result from such reflection on one's past attachments.

The study also revealed a tendency for young adolescents with seemingly secure attachments, to identify themselves with the standards of their parents or other 'significant others'. They also tend to transfer attachment components to God, and through such transfer they redefine their concept of God and their belief of what and how God can have a significant impact on their lives. "I don't live without the love for animals and their love towards me... even though I know that every relationship has an end... and that will greatly hurt... Though I was never brought up by my parents, I always had a very good relationship with my grandmother and aunt who raised me...they meant everything to me... they were my world... and they always taught me that God not only exists but He guides and assists us all throughout our life journey...if we pray to Him He would always listen and attend to our prayers in ways he deems best...He is our companion, just as these people were to me...”. 


\subsubsection{The Need for Healing through Empathy and Compassion}

"It feels so good to be able to express and share my own personal experiences.... and to be listened to and empathized with...I did not feel embarrassed to show my emotions, and even cry...I felt my friends' love through their compassion...”. This statement, or rather, sincere expression, of one of the student participants, well represents a general sentiment that was experienced by almost all the participants in this study. Most of them felt that even through the expression and sharing of personal experiences they could experience the positive emotions of acceptance, empowerment, self-belief in their inner resources, joy and serenity of the heart, experiencing healing in the process and as a result. Such healing, thus, transpired from empathy and compassion, that were only possible in a community context characterized by true friendship, care and mutual concern and positive regard. As one female student put it:

Student: We felt so close, more than ever before, and certainly much more than we could ever feel in class or at school. And we showed and felt so much empathy and compassion through and for each other...

Researcher: Do you think this experience could be replicated in the school classroom, albeit in different ways and forms?

Student: Yes, of course! Then Religion (subject) would become everybody's favourite...

Researcher: But you would still go home and have to face your problems and challenges...may be with no tangible solutions

Student: Yes....but with a very different feeling and attitude... and with courage and belief that you can make something out of yourself and that you are loved and supported....that makes all the difference! I feel someone!

When I further challenged the students to tell me whether they believe God has a role in such a dynamic that was creating such feelings of encouragement, empowerment and healing, they either attributed their origin to God, or expressed their satisfaction irrespective of what caused such a dynamic to be effective. One of the three students who described themselves as either atheist or agnostic, with respect to the belief in God or some kind of divinity or higher power, stated that:

Student: Even though I don't believe in God, or at least I have to say that I don't really care whether he could possibly exist or not, I still believe that we need to be healed, and this we could experience by healing each other...

Researcher: Let's imagine a scenario in which God existed, and he was in deed and truly compassionate as Jesus was. How would you look at him and what would your reaction be towards him? 
Student: That would be just great. Great for me and for every hurt person in this world. It's what we all need... right? But we have never seen and could never see a God who is human and has human qualities, whether good or bad... that is what I think...

Researcher: And if I had to tell you that Jesus is God, or at least, he transmits to us the power to be compassionate like him, so that what we give to and receive from each other always comes through him, what would you say?

Student: I'd say 'great'...that's what we all need, that what the world needs. But I don't believe that... what I believe is that people like Jesus can really and truly inspire us to show compassion and solidarity... and be kind to each other...

Such words can easily be interpreted, by the Catholic believer through faith, as an explicit manifestation of Rahner's concept of the supernatural existential.

\subsubsection{Adolescents' Need for Authenticity as a Source of Holistic Maturity}

Student: To me one of the best feelings I had throughout this project was a sense of satisfaction for being myself. I could be myself without fear of being judged or intimidated or threatened in some way. I felt accepted for what I am...

Researcher: How would you think of God if he had to exist and have this same character: non-judgmental, loving, caring and compassionate, irrespective of what you did and what you think about anything?

Student (smiling): I would say I am his greatest fan and admirer... and certainly would think differently of faith and religion...definitely so!!!

This statement, taken from a student's interview, expresses very explicitly and powerfully, the adolescents' need for a sense of authenticity and for their search for spaces in which they could be authentic. All throughout this research project's journey, students explicitly and/or implicitly expressed their need to voice their life stories, and how their ideas, perspectives, opinions, world and faith views were shaped through these stories. They also experienced the positive benefits and resulting emotions of being able to morally evaluate their past experiences and critically reflect upon them, re-interpreting and re-configurating them in the process. This would then empower them in the hope for a better future, and equip them with a sense of resilience to face life challenges ahead.

It was also very interesting and encouraging to observe the educational dynamic between empathy and authenticity. When students felt they could 'be themselves' and 'true to themselves' and simultaneously feel safe, respected, empathized with and cared for, they could feel free enough to re-define their 
identity, explore possible ways of being and acting, dream new pathways ahead, and re-think the source/s of their transcendental exploration (in terms of meaning-making). Thus, even if they came in thinking of themselves as atheists or agnostics, indifferent in or even antagonistic for religion and faith, their freedom gave them the synched openness of mind and heart to question about God and faith related issues that have a significant bearing on one's identity in both the present and the future. This was captured so well in a comment by a student during an in depth interview:

Student: I never imagined I could be myself and speak my own mind at school, let alone during the Religion class. I always believed that my thoughts and ideas would never be accepted and respected... or even listened to... in a Catholic environment.

Researcher: And now that you found the appropriate space and opportunity to be yourself and speak your own mind, how do you feel? And how has it changed your way of thinking, and you as a person?

Student: I simply feel relieved...so relieved!!! And grateful for this (very emotional, almost crying). I think that now I am ready to re-think and may be revise the way I used to think of faith, of God, of Church... and of myself... I mean my value as a unique person.

\subsubsection{Adolescents' Level of Engagement in CRE through Media Production}

Many of the participants' responses in the questionnaires and interviews reveal their strong belief that photography and film-making san serve as catalysts for creativity, through which students can be highly engaged in learning various curricular subjects, such as CRE. "Made me comfortable to express myself creatively, and that was not boring at all. The fact that you go out taking pictures and footage to create a video that explains your personal faith is different to how we usually learn. That makes it even more appealing...”.

Many of those interviewed acknowledged that their decision to self-disclose personal experiences was facilitated by the short videos they produced. They admitted that through such media they could express what otherwise would be difficult, and too embarrassing to articulate. Moreover, each video they watched encouraged them more to express and share their own experiences, and enriched their reflection on their own production n. "I believe the videos helped a lot. If only we are given such opportunities to use videos in the CRE and PSCD lessons! It would help a lot, especially if you are shy and 
find it difficult to express yourself in front of the class...the video will do the talking in front of the class."

\section{Reflections on a Narrative Pedagogy Marked by Empathy, Authenticity and Compassion}

It comes out very clearly and powerfully from this research that students, irrespective of their social, cultural, religious and/or denominational background, expect, and even crave for empathy, authenticity and compassion in their relationships, especially from family members, educators and fellow students in an educational context. All student participants acknowledged that such virtues are the most real and powerful source of healing and holistic self-growth, as well as empowerment and resilience in the face of life anxieties and adversities.

In an article that he had written in 2008 for the New York Times, William Safire explains clearly how and why real empathy goes beyond mere sympathy. He states, in a personalized manner, that: "If you think empathy is the synonym of sympathy, I'm sorry for your confusion. Back to the Greeks: pathos is "emotion." Sympathy feels pity for another person's troubles, secondarily a sense of allegiance; empathy identifies with whatever is going on in another's mind or in a work of art - visual, dramatic, musical - whether merry or morose, hanging loose or uptight. The Greek prefix sym means "together with, alongside"; the verbal prefix em goes deeper, meaning "within, inside." When you're sympathetic, your arm goes around the shoulders of others; when you're empathetic, your mind lines up with what's going on inside their heads. Big difference..."

Moreover, in the process of developing empathy with other human beings, we reach beyond our life experiences, as we "feel with" others. Through empathy we learn how to be listen carefully and present to, as well as come in tune with the feelings and needs of others. Compassion occurs as we start feeling deep empathy and respect for another who is stricken by misfortune, and the strong desire to actively do something about it. In other words, compassion is the human quality of understanding the suffering of others paired with a desire

${ }^{90}$ W. Safire, Nuance, "New York Times Magazine", MM24 September 52008, available online at htps://www.nytimes.com/2008/09/07/magazine/07wwln-safire-t. html? searchResultPosition $=37$. 
to help alleviate it. ${ }^{91}$ Thus, empathy and compassion both stem out of a deep kind of listening in the form of as experiential attention. Compassion, however, goes further and deeper in its commitment to act on feelings experienced, seeking to sooth, help, care and show acceptance and unconditional positive regard. Many research studies show that these two attributes, or better still, virtues in education, are strongly and positively correlated with an environment that cultivates unconditional positive regard, that in turn fosters resiliency and hope through which one's sense of self that has been damaged by trauma and/ or marked by pain, can be restored. In this way, students can feel empowered to re-imagine their lives and strive towards their dreams, and encourage others to do the same..$^{92}$ Karen Anderson argues that empathy and compassion are not only crucial elements for the well-being of cultures but also foundational paths to happiness for individuals. Her research on ancient and modern religions shows that the majority of religions emphasize compassion and empathy as keys to individual enlightenment and as the true test of spirituality. ${ }^{93}$ These attributes can significantly help in avoiding interpersonal and intercultural conflict, as well as achieving a more fulfilling and happy life. In this regard, they deserve close consideration. Thus, empathy and compassion are vital elements of transformative learning in religious education. Moreover, as this study clearly demonstrates, these virtues which have so much healing power, can be mostly transmitted and received through storytelling, as it is through stories that we, as human beings, can make sense of our lives and build shared realities. This perspective, shared by many educators, transpires from the fact that humans are storytellers by nature. ${ }^{94}$ Furthermore, since in the present digital age our

${ }^{91}$ R. Wolpow, M.M. Johnson, R. Hertel, S.O. Kincaid, The Heart of Learning and Teaching: Compassion, Resiliency, and Academic Success, Washington State Office 2009 (Third printing in May 2016).

${ }^{92}$ M. E. Hess, Finding a Way into Empathy through Story Exercises in a Religious Studies Classroom, in: J.L. Tinklenberg (Ed.), Empathy and the Religious Studies Classroom Spotlight on Teaching, American Academy of Religion 2020; R. Wolpow, M.M. Johnson, R. Hertel, S.O. Kincaid, The Heart of Learning and Teaching: Compassion, Resiliency, and Academic Success, Washington State Office 2009 (Third printing in May 2016).

${ }^{93}$ R. Anderson, Intuitive inquiry: the ways of the heart in human science research, in: R. Anderson, W. Braud (Eds.), Transforming Self and Others through Research: Transpersonal Research Methods and Skills for the Human Sciences and Humanities, Albany 2011, SUNY, pp. 15-70.

${ }^{94}$ M. E. Hess, Finding a Way into Empathy through Story Exercises in a Religious Studies Classroom, in: J.L. Tinklenberg (Ed.), Empathy and the Religious Studies Classroom Spotlight on Teaching, American Academy of Religion 2020. 
students are immersed in vast oceans of narratives, the process of meaningmaking through the narrative-hermeneutical-developmental approach has the potential of facilitating transcendental reflection and spiritual growth around the dynamics of agency and authenticity. This is crucially important since in this age a story's source of authority has shifted from authoritative figures to one's personal realm that is strengthened by agency and authenticity. ${ }^{95}$ In several academic discussions about the relationship between education and authenticity, advocates express both confidence and an optimistic outlook towards their positive correlation, resulting in a sense of synergy between effective pedagogical strategies and the development of authenticity in students. Such strategies transpire from and follow constructive developmental perspectives of and on learning, ${ }^{96}$ and therefore, the narrative-hermeneutical-developmental approach discussed in this paper could greatly benefit from them. The adoption of such strategies are even commendable as they actively involve students in determining what is learnt and how. ${ }^{97}$ Authenticity is always about interiority, and how a sense of self can be discovered and accessed through introspection, as it is manifested in people's daily existence. Its conceit, however, is that our students can, through appropriate ways of thinking, "access some well-defined self that stands out as authentic compared to inauthentic alternatives." ${ }^{\prime 98}$ Such privileged access to the essential 'me' is often less easy than it sounds. ${ }^{99}$ To say that students should be authentic is to endorse their own authority on matters of identity, and often other matters, without yet knowing who or what else they could be. Moreover, and most importantly, coupling authenticity with agency

${ }^{95}$ M.E. Hess, Responding to the Challenges of Religious Storying in a Digital Age: Building New Opportunies through Feautor.org, in: Y. Gächter (Ed.), Erzählen - Reflexionen im Zeitalter der Digitalisierung / Storytelling - Reflections in the Age of Digitalization, Innsbruck 2008, Innsbruck University Press, pp. 112-126; M.E. Hess, Exploring the Epistemological Challenges Underlying Civic Engagement by Religious Communies, "The Good Society Special Issue: On Reintegrating Facts, Values, Strategies” 26:2-3 (2017), pp. 305-322.

${ }^{96}$ M. Baxter-Magolda, Creating Contexts for Learning and Self-Authorship: ConstructiveDevelopmental Pedagogy, Nashville, TN 1999, Vanderbilt University Press.

97 C. Kreber, Academics' teacher identities, authenticity and pedagogy, "Studies in HigherEducation" 35:2 (2010), pp. 171-194; L.J. Splitter, Authenticity and constructivism in education, "Studies in Philosophy andEducation" 28:2 (2009), pp. 135-151.

98 L. Bialystok, P. Kukar, Authenticity and empathy in education, "Theory and Research in Education" 16:1 (2018), p. 27.

${ }^{99}$ L. Bialystok, Authenticity and the limits of philosophy, "Dialogue: Canadian Philosophical Review" 53:2 (2014), pp. 271-298. 
in CRE creates opportunities to express and reflect upon personal experiences through a transcendental lens. In this way students can grow spiritually through, not despite, of the Catholic tradition, even if they are not or do not consider themselves to be Catholics or even believers. As has been shown in this paper and the research project it reported and analysed the results of, this endeavour could be possible when spirituality is understood in its natural dimension, and through it, CRE can incarnate God's presence and revelation in the human heart. Thus, the starting and entry point of every topic, issue and/or learning outcome of CRE, as well as its source and locus of relevance, becomes the human spiritual dimension that is universal, not synonymous with religiosity, and not dependent on whether a person has religious belief or not. This is the human spiritual dimension envisaged as the natural dimension of life that includes: "thinking and feelings about transcendence; ideas about a creator or creative force in the cosmos; human values; sense of meaning and purpose in life; love and care for self and others; sense of stewardship for the earth and its flora and fauna; the aesthetic. Spirituality is the way in which a spiritual/moral dimension enters into, or is implied in, the thinking and behaviour of individuals."100

This paper and this research have argued that such a pedagogy can be applied through a narrative-developmental-hermeneutic approach that is marked by empathy and compassion. This requires the nurturing the ability in students to actively listen to and speak one's own story while respecting its complexity, as well as the capacity to engage other stories, particularly those which might confront, challenge, or even counter our personal stories. When teachers learn how to help their students to slow down enough to listen to their own stories, as well as provoke their curiosity to listen to the stories of their peers while in a state of wonder rather than fear, they would be creating an environment conducive to the manifestation and experience of empathy and compassion that bring about healing, connection, transcendence and empowerment. ${ }^{101}$

${ }^{100}$ G. Rossiter, A case for a 'big picture' re-orientation of K-12 Australian Catholic school religious education in the light of contemporary spirituality, "Journal of Religious Education" 58:3 (2010), p. 7; G. Rossiter, Understanding the Changing Landscape of Contemporary Spirituality: A useful starting point for reviewing Catholic school religious education, "The Person and the Challenges" 3 (2013) No. 1, pp. 157-179.

${ }^{101}$ M. E. Hess, Finding a Way into Empathy through Story Exercises in a Religious Studies Classroom, in: J.L. Tinklenberg (Ed.), Empathy and the Religious Studies Classroom Spotlight on Teaching, American Academy of Religion 2020, p. 32. 


\section{God's Revelation, Spirituality (Transcendence) and a Narrative-Hermeneutical-Developmental Approach to Learning: Deep Connection and Road to Healing}

As this paper has already showed through an analysis of Rahner's distinctive theology, especially in his anthropological turn in relation to the notion of revelation, the experience of God is never reserved to a select few, but is always an entitlement of every human person, as all human beings are willed, desired, as well as created by the same God. This is why Rahner, in his writings, frequently reflects on the God experience of every person, and would even call an ordinary person a 'mystic.' This explains the significance of the German theologian's frequently quoted statement, "The Christian of the future will be a mystic or he will not exist at all."102 In the context of his theology and philosophy, Rahner never understood 'mysticism' as a phenomenon that is parapsychological, but a genuine experience of God that emerges from the depths of the human heart and human existence. One of the main implications of such a stance is that since human beings are created by God out of an act of love, God knows how to relate with them in ways known to him alone. Thus, through his concept of the 'supernatural existential', Rahner shows how transcendental enquiry is indeed a 'theological' investigation, and explores how the transcendental openness of the human heart is linked to the Christian idea of revelation, both in grace and in history. This openness occurs irrespective of one's religious beliefs, and explains why revelation and human nature are intimately connected. ${ }^{103}$

The research reported and analysed in this paper has sought to bring to light how this intimate connection can be experienced in CRE through a narrative-hermeneutical-developmental pedagogical approach, and facilitated by creative digital technologies that provide a significant context to students abiding virtual reality in this time and age. By creating a synergic relationship between Rahner's theology of transcendence and this narrative-hermeneuticaldevelopmental pedagogy in CRE, the value of the Catholic faith is brought to light and life. Concretely, and pedagogically, this occurs when CRE's main aim ceases to be the transmission of doctrine, but the universal need

${ }^{102}$ K. Rahner, Christian Living Formerly and Today, “Theological Investigations VII” (trans. by D. Bourke), Herder and Herder 1971, p. 15.

${ }^{103}$ J. Xavier, Rahner's 'Anthropological Turn' in Theology and Doctrine of Revelation, "Asian Horizons" 8:2 (2014), p. 359. 
for spiritual (transcendental) development and maturity that transpire from a narrative process embedded in meaning-making. Everything that human beings encounter in life can translate into opportunities for an encounter with God, and thus become a channel of his grace. Such encounters, especially with one's life story and that of others, can potentially become sacraments of God's love, through deep reflection, imagination inspired by hope, appropriate interpretation (through the power of God's Spirit, occurring both explicitly and implicitly), and prayer from the heart. This, however, calls for a pedagogy inspired by agency and authenticity that are embedded in a strong sense of reciprocal empathy and compassion.

\section{Conclusion}

At the heart of the Christian faith one will always find the convict on that God has always entered into a personal relationship with and spoken to human beings. Every true Christian believes that this revelation as the self-communication of God in grace and history is not only reserved for the select few, or for those who profess themselves as Christians, but to all people. Moreover, the Christian also knows that the true meaning and purpose of God's Incarnation in Jesus Christ is for Him to communicate with the whole of humanity. The most important implication that transpires from these convictions, in today's world, is the urgent task of theology to make the Christian faith credible. This becomes a reality when people understand that their daily experiences are part of their whole lives, including their spiritual lives and transcendental longings and struggles. Only then the unity of the two commands - love of God and love of neighbour - would make sense and becomes a reality in their everyday lives. This truth affirms powerfully that the human experience cannot be ignored while talking about faith, religion, and God. Furthermore, the Christian faith has never been and will never be a second-hand experience of God transmitted by the chosen privileged few, but the experience that God offers of Himself to everyone, as every person is created in His own image and likeness, and like him called to love and be loved. Rahner shows us, as this paper highlighted, that all human beings can have experiences of God through their everyday activities, actions and encounters. In this way faith becomes personal and responsible, as every human person is the addressee of God's initiative. Thus, all human experiences, both worldly and spiritual, can potentially signify 
that "deeply inscribed in our hearts is an orientation to God and to his word of revelation."104 Simultaneously, Rahner believes that in and through Jesus Christ, God draws near to us personally and calls all human beings to enter into communion with him. "In its culminating expression, revelation is the good news that God is with us (Emmanuel) to free us from the darkness of sin and to raise us up to life eternal." ${ }^{\text {"105 }}$ For Rahner, theology is the "science of faith"106, as it is based on the belief that God has given to every human being abundant light, both natural and supernatural, to discern and feel His presence in this world, and find meaning and fulfilment in life, amidst all the surrounding and inner anxiety, pain, anguish, fears and sense of absurdity.

The empirical research study reported in and reflected upon in this paper has sought to apply this theology to the 'praxis' of CRE. Consequently it could hopefully contribute to more understanding through exploration, of ways how Catholic religious educators can adopt and apply a pedagogy of empathy, agency, authenticity and compassion through creative digital technologies in the context of CRE as a curricular subject. In this way students, whether practicing and/or professing Catholics or not, can engage in transcendental reflection, through a narrative-hermeneutical-developmental approach that nurtures their spiritual growth, resulting in a sense of holistic wellbeing that is further strengthened and motivated by meaning that provides direction to their lives. Thus, CRE would provide a safe and comfortable space in which they learn to express their own and listen to each others' stories, show and feel empathy and compassion in the process, and experience healing through all the benefits that spiritual growth provides, especially holistic wellbeing and resilience that increases in moments of pain and adversity. Their stories become 'primordial words' that are transformed into sacraments of God's healing love, as they are uttered and listened to. As, since according to Rahner, every human person is by nature a hearer of God's Word (that is also asserted by the Catechism of the Catholic Church) ${ }^{107}$, the very act of listening to human stories embedded in metaphor and transcendental

\footnotetext{
${ }^{104}$ J. Xavier, Rahner's 'Anthropological Turn' in Theology and Doctrine of Revelation, "Asian Horizons" 8:2 (2014), p. 21.

${ }^{105}$ J. Xavier, Rahner's 'Anthropological Turn' in Theology and Doctrine of Revelation, "Asian Horizons" 8:2 (2014), p. 21.

${ }^{106}$ K. Rahner (Ed.), Theology: Nature, "Encyclopedia of Theology: The Concise Sacramentum Mundi”, New York 1975, Seabury, p. 1687.

107 Catechism of the Catholic Church, par. 27.
} 
reflection, even in CRE, becomes God's way of bandaging human wounds and pouring oil and wine on them. The parable of the Good Samaritan becomes enfleshed in each CRE class, as it is frequently in suffering and tribulation that God comes across through the human touch.

\section{Bibliography}

Anderson R., Intuitive inquiry: the ways of the heart in human science research, in: R. Anderson, W. Braud (Eds.), Transforming Self and Others through Research: Transpersonal Research Methods and Skills for the Human Sciences and Humanities, Albany 2011, pp. 15-70.

Arnett J.J., Emerging adulthood: A theory of development from the late teens through the twenties, "American Psychologist" (55) 2000, pp. 469-480.

Atkinson R., The gift of stories: Practical and spiritual implications of autobiography, life stories and personal mythmaking, Westport, C.T: Bergin \& Garvey 1995.

Atkinson R., The life story interview, in G.J.F. Holstein (Eds.), in: Handbook of Interview Research: Context and Method, Sage Publications 2002, Thousand Oaks CA, pp. 121-140.

Baumeister R.F., Wotman S.R., Stillwell A.M., Unrequited love: On heartbreak, anger, guilt, scriptlessness, and humiliation, "Journal of Personality and Social Psychology" (64) (1993), pp. 377-394.

Baxter-Magolda M., Creating Contexts for Learning and Self-Authorship: Constructive Developmental Pedagogy, Vanderbilt University Press Nashville Tennissee 1999.

Berger J.G., Exploring the connection between teacher education practice and adult development theory, Doctoral dissertation, Harvard University 2002.

Bialystok L., Authenticity and the limits of philosophy, "Dialogue: Canadian Philosophical Review" (53:2) (2014), pp. 271-298.

Bialystok L., Kukar P., Authenticity and empathy in education, "Theory and Research in Education" (16:1) (2018), p. 27.

Bianchi E., Living with elder wisdom, in H.R.Moody (Ed.), in: "Religion, spirituality and aging: A social work perspective", Binghamton, NY: Haworth Press 2005, p. 321.

Book of Revelation, in: The New Jerusalem Bible, Darton-Longman \& Todd, London 1990.

Brockelman P., The inside story: A narrative approach to religious understanding and truth. Albany, New York 1992.

Bruner J.S., Wiesser S., The invention of self: Autobiography and its forms, in: D.R. Olsen, N. Torrance (Eds.), Literacy and orality, Cambridge University Press, New York 1991, pp. 129-148.

Bussing A., Foller-Mancini A., Gidley J., Heusseur P., Aspects of spirituality in adolescence, "International Journal of Children's Spirituality" 15(1) (2010), pp. 25-44.

Catechism of the Catholic Church, par. 27. 
Clark M.C., Narrative Learning: Its Contours and Its Possibilities, "New Directions for Adult and Continuing Education" (2010), p. 6.

Dettori G., Paiva A., Narrative Learning in Technology-Enhanced Environments, in: N. Balacheff et al. (Eds.), Technology-Enhanced Learning: Principles and Products, 2009, pp. 55-69, DOI: 10.1007/978-1-4020-9827-7_4.

Dulles A., Models of Revelation, Doubleday \& Company 1983, p. vii.

Dulles A., The Symbolic Structure of Revelation, "The Catholic University of America” 41:1 (1980), p. 56.

Hair E.C., Moore K.A., Garrett S.B., Ling T., Cleveland K., The continued importance of quality parent-adolescent realtionships during late adolescence, "Journal of Research on Adolescence" (18) (2008), pp. 187-199.

Happel S., Response to William Van Roo, "Proceedings of the Catholic Theological Society of America” 32 (1977), p. 119.

Harter S., Monsour A., Developmental analysis of conflict caused by opposing attributes in the adolescent self-portrait, "Developmental Psychology" (28) (1992), pp. 251-260.

Hay D., Nye R., The spirit of the child, Jessica Kingsley Publishers: London 2006.

Hess M.E., Responding to the Challenges of Religious Storying in a Digital Age: Building New Opportunies through Feautor.org, in: Y. Gächter (Ed.), "Erzählen - Reflexion en im Zeitalter der Digitalisierung / Storytelling - Reflections in the Age of Digitalization", Innsbruck University Press, Innsbruck 2008, pp. 112-126.

Hess M.E., Exploring the Epistemological Challenges Underlying Civic Engagement by Religious Communies, The Good Society Special Issue: On Reintegrating Facts, Values, Strategies" (26:2-3) (2017), pp. 305-322.

Hess M.E., Finding a Way into Empathy through Story Exercises in a Religious Studies Classroom, in: J.L. Tinklenberg (Ed.), "Empathy and the Religious Studies Classroom Spotlight on Teaching", American Academy of Religion 2020.

Holmes A., Conway M.A., Generation identity and the reminiscence bump: Memory for public and private events, "Journal of Adult Development" (6) (1999), pp. 21-34.

Kegan R., In over our heads: The mental demands of modern life, Harvard University Press, Cambridge MA 1994, p. 17.

Kitchener K.S., Lynch C.L, Fischer K.W., Wood P.K., Developmental range of reflective judgment: The effect of contextual support and practice on developmental stage, "Developmental Psychology" (29) (1993), pp. 893-906.

Knitter P., Theologies of Religions, New York 2002.

Kokkos A., The process of transformation: Kegan's view through the lens of a film by Wenders, in: Paper presented during conference titled What's the point of Transformative Learning, Athens 2014 (Proceedings), pp. 106-107.

Kreber C., Academics' teacher identities, authenticity and pedagogy, "Studies in Higher Education" (35:2) (2010), pp. 171-194.

Kroger J., Identity development during adolescence, in: G.R. Adams, M.D. Berzonsky (Eds), "Blackwell handbook of adolescence", Blackwell, Malden MA 2003, pp. 205-226. 
Lau B., Wordsworth's The Prelude and self-defining memories, in: L.H.Peer (Ed.), Recent perspectives on European romanticism, The Edwin Mellon Press, Lewiston M.E 2002, pp. 93-103.

Lunde-Whitler J.H., Paul Ricoeur and Robert Kegan in Unlikely Dialogue: Towards A "Narrative-Developmental" Approach to Human Identity and Its Value for Christian Religious Education, "International Journal of Practical Theology" (19:2) (2015), p. 295, DOI: https://doi.org/10.1515/ijpt-2014-9001.

Masson R., Rahner's Primordial Words and Bernstein's Metaphorical Leaps: The Affinity of Art with Religion and Theology, "Horizons" Vol. 33 (2) (2006), pp. 276-297.

McAdams D., Power, intimacy and the life story: Personological inquiries into identity, Guilford New York 1988, pp. 215-251.

McAdams D.P., The psychology of life stories, "Review of General Psychology” (5) (2001), pp. 100-122.

McLean K.C., Late adolescent identity development: Narrative meaning making and memory telling, "Developmental Psychology" (41) (2005), pp. 683-691.

Mezirow J., Fostering Critical Reflection in Adulthood, San Francisco California 1990.

Mezirow J., Transformative Dimensions of Adult Learning, San Francisco California 1991.

Mezirow J., Transformative Learning: Theory to Practice. New Directions for adult and Continuing Education, (74) 1997, pp. 5-11.

Nelson A., Imagining and critical reflection in autobiography: An odd couple in adult transformative learning, in: Adult Education Research Conference, Paper 33 June 30, 1997, http://newprairiepress.org/aerc/1997/papers/33

Pasupathi M., Hoyt T., The Development of Narrative Identity in Late Adolescence and Emergent Adulthood: The Continued Importance of Listeners, "Developmental Psychology" (45:2) (2009), pp. 558-574.

Polanyi M., The Study of Man. University of Chicago Press, Chicago 1964.

Polkinghorne D.E., Narrative Knowing and the Human Sciences, State University of New York Press, New York 1988, p. 142.

Polkinghorne D.E., Narrative Knowing and the Human Sciences, State University of New York Press 1988.

Rahner K., An Introduction to the Idea of Christianity, New York 1978.

Rahner K., Theological Investigations, Baltimore 1961: Helicon Press.

Rahner K (Ed.)., Theology: Nature, in: Encyclopedia of Theology: The Concise Sacramentum Mundi, Seabury New York 1975, p. 1687.

Rahner K., Foundations of Christian Faith, London 1978: Darton-Longman \& Todd, p. 132.

Rahner K., Christian Living Formerly and Today, in: Theological Investigations VII (trans. by D. Bourke), Herder and Herder 1971, p. 15.

Randall W.L., Transcending Our Stories: A Narrative Perspective on Spirituality in Later Life, "Critical Social Work" 10:1 (2009), pp. 31-40.

Ricoeur P., Time and Narrative I, The University of Chicago Press, Chicago 1984. 
Ricoeur P., Life in Quest of Narrative, in: D. Wood (Ed.), On Paul Ricoeur: narrative and interpretation, Routledge, London and New York 1991, pp. 20-33.

Ricoeur P., Oneself as Another. The University of Chicago Press, Chicago 1992.

Ricoeur P., Hermeneutics and the human sciences (17th edn.), J. B. Thompson (Trans., Ed.), Cambridge University Press, Cambridge MA 2005.

Rossiter G., A case for a 'big picture' re-orientation of K-12 Australian Catholic school religious education in the light of contemporary spirituality, "Journal of Religious Education" (58:3) (2010), p. 7.

Rossiter G., Understanding the Changing Landscape of Contemporary Spirituality: A useful starting point for reviewing Catholic school religious education, "The Person and the Challenges" 3 (2013) No. 1, pp. 157-179.

Safire W., Nuance, New York Times Magazine, MM24 September 5 2008, htps://www. ny冈mes.com/2008/09/07/magazine/07wwln-safire-t.html?searchResultPosi冈on=37.

Scales P.C., Syvertsen A.K., Benson P.L., Roehlkepartain E.C., Sesma A., Relation of Spiritual Development to Youth Health and Well-Being: Evidence from a Global Study, 2014, DOI: 10.1007/978-90-481-9063-8_41.

Schafer R., Narration in the psychoanalytic dialogue, in: W.J.J. Mitchell (Ed.), On Narrative, University of Chicago Press, Chicago 1981, pp. 25-49.

Singer J.A., Narrative identity and meaning-making across the adult lifespan, "Journal of Personality" 72(3) (2004), pp. 437-459.

Spence D.P., Narrative truth and historical truth: Meaning and interpretation in psychoanalysis, Norton, New York 1982.

Splitter L.J., Authenticity and constructivism in education, "Studies in Philosophy and Education" (28:2) (2009), pp. 135-151.

Sutin A.R., Robins W.R., Continuity and correlates of emotions and motives in self-defining memories, "Journal of Personality" (73) (2005), pp. 793-824.

Taylor C., Sources of the Self: The Making of Modern Identity, Harvard University Press, Cambridge MA 1989.

Taylor C., Multiculturalism: Examining the Politics of Recognition, Princeton University Press, New Jersey 1994.

Taylor C., Philosophical Arguments, Harvard University Press, Cambridge MA 1995.

Underwood L.G, Teresi J.A., The daily spiritual esperience scale: Development, theoretical description, reliability, exploratory factor analysis, and preliminary construct validity using health-related data, "Annals of Behavioral Medicine" (24) (2002), pp. 22-33.

Vermeer P., Van der Ven J., Religious Identity Formation: An Educational Approach, "International Journal of Education and Religion" (2:2) (2001), p. 109.

White M., Epston D., Narrative means to therapeutic ends, Nortobn, New York 1990.

Wolpow R., Johnson M.M., Hertel R., Kincaid S.O., The Heart of Learning and Teaching: Compassion, Resiliency, and Academic Success, Washington State Office 2009 (Third printing in May 2016). 
Xavier J., Rahner's 'Anthropological Turn' in Theology and Doctrine of Revelation, "Asian Horizons" (8:2) (2014), p. 359.

Yeats W.B., William Blake and His Illustrations to the Divine Comedy, in: Collected Works 6, Stratford-on-Avon: Shakespeare Head Press 1908, p. 138.

Zhao K., Biesta G., The Moral Dimension of Lifelong Learning: Giddens, Taylor, and the "Reflexive Project of the Self", "Adult Education Quarterly" (62:4) (2012), pp. 332-350. 